WIELKIE TEMATY KULTURY W LITERATURACH SŁOWIAŃSKICH

Slavica Wratislaviensia CLXVIII • Wrocław 2019•AUWr No 3875

DOI: 10.19195/0137-1150.168.52

Data przesłania artykułu: 27.09.2017

Data akceptacji artykułu: 10.12.2017

\author{
SNEŽANA BOŽIĆ \\ Univerzitet u Nišu, Serbia
}

\title{
Obrada motiva smrti u nastavi književnosti
}

Dobar način da se predstavi suština onoga čime se u radu bavimo je Senekina misao koja glasi: „Uskoro ćemo ispustiti poslednji dah. U međuvremenu, dok živimo, dok smo među ljudima, negujmo svoju čovečnost”. To „negovanje čovečnosti" jedan je od najvažnijih opštih ciljeva nastave književnosti i ogleda se $\mathrm{u}$,humanizovanju i socijalizovanju ličnosti učenika”2.

Jasno je, iz navedenog, da nas primarno interesuje metodički (nastavni) kontekst u koji se motiv smrti uvodi preko književnog teksta koji se obrađuje na času. Cilj našeg istraživanja bio je da ispitamo da li je i u kojoj meri smrt tabu tema u učionici, odnosno kako joj se pristupa onda kada se ne može izbeći, kada predstavlja središnji motiv nastavnim programom zadatog književnog dela. Posebno je, čini se, pitanje važno ako uzmemo u obzir to da se sa relevantnih stručnih pozicija povremeno stavlja do znanja da je kriterijum prilikom izbora tzv. „kanonskih” tekstova, tj. tekstova školske lektire, izbegavanje, odnosno dozirano plasiranje "teških tema" ${ }^{3}$, pa se pri konstituisanju kanona prednost daje „,vedrijim stranama ljudskog života, primerenim i razumljivim đacima osnovne škole"4 . Ovakvi stavovi implicitno sugerišu da su ,teške" teme neprimerene i ne-

${ }^{1}$ Prema M. Nusbaum, Negovanje čovečnosti: klasična odbrana reforme liberalnog obrazovanja, prev. S. Glišić, „Reč” 2012, br. 82/28, s. 275.

2 Ovaj opšti cilj postiže se ostvarivanjem niza tzv. bližih nastavnih ciljeva, koji se uspostavljaju za svaki pojedinačni književni tekst predviđen za obradu, pri čemu za ostvarivanje vaspitnih (i bližih i daljih) ciljeva nužan preduslov predstavlja ostavarivanje onih sa estetskog područja. „Umetnički tekst treba prvo da uzbudi i oduševi učenike, da im opsedne maštu i misli, pa da tako, u svojstvu snažnog ličnog doživljaja ubedljivo deluje na moralne stavove i ponašanje." M. Nikolić, Metodika nastave srpskog jezika i književnosti, Beograd 2006, s. 19.

${ }^{3}$ Z. Mrkalj, Na časovima srpskog jezika i književnosti, Beograd 2011, s. 10.

${ }^{4}$ Ibidem, s. 81. 
razumljive učenicima, te ih treba izbegavati ${ }^{5}$. Upravo svest o saznajnoj i vaspitnoj funkciji nastave književnosti (uključujući i estetsku) podrazumeva da je treba smatrati legitimnim, čak naročito pogonim oruđem za kultivaciju doživljaja, mišljenja i stavova učenika koje takve teme i životne zapitanosti kod njih pokreću.

Zato nas je zanimalo u kojoj meri tekstovi sa istaknutim motivom smrti zahtevaju metodički promišljeniji pristup i pažljiviju pripremu nastavnika; koje postupke motivisanja učenika za čitanje i analizu takvih tekstova oni primenjuju; kako se u toku samog analitičkog razgovora o tekstu tretira pojam smrti (da li se verbalizuje i promišlja ili prećutkuje i zaobilazi); koliko je nastavnikovo metodičko postupanje uslovljeno uvidom koji on ima u iskustvo svojih učenika sa smrću; da li primat $u$ analitičkim razgovorima nastavnik daje vaspitnim ili saznajnim ciljevima i na koji način te ciljeve formuliše... Iako se čini da nas neka od ovih pitanja udaljavaju od samih književnih tekstova, usmeravajući istraživačku pažnju u većoj meri ka psihološko-pedagoškom polju, gde se pojedini odgovori najjednostavnije mogu pronaći, uvereni smo da se rešenja za najbolja nastavna postupanja kriju upravo u kompleksu i sintezi interdisciplinarnih znanja koje nastavnik aktivira prilikom kreiranja sopstvene nastavne metodologije, a koja dolaze iz nauke o književnosti kao predmetne i niza tzv. korespondirajućih nauka, u ovom slučaju prvenstveno iz psihologije i pedagogije. U tom smislu, izvore metodičkih refleksija o samoj temi (poimanje i pristup motivu smrti na času književnosti), kao i definisanja empatijsko-etičkog modela čitanja književnog teksta koji želimo da primenimo, predstavljaju radovi iz oblasti afektivne naratologije, potom iz komplementarnih oblasti afektivne i kognitivne psihologije, kao i šireg, humanističkog koncepta obrazovanja, odnosno studije koje u postavkama i razmatranjima objedinjuju aspekte emocija, kognicije i recepcije književnog dela.

Znanja koja nastavnik književnosti poseduje o dečijem poimanju koncepta smrti ili psihološkim preporukama o načinima na koje se sa decom određenog uzrasta i ne/iskustva o smrti razgovara, metodički su relevantna i predstavljaju važan aspekt nastavnikovih promišljanja o adekvatnom pristupu tekstovima školske lektire u kojima je prisutan motiv smrti. To je, pored ostalog, potvrđeno i rezultatima empirijskog istraživanja, koje smo sproveli kao onlajn anketiranje nastavnika srpskog jezika i književnosti ${ }^{6}$. U anketi je učestvovalo stotinu (100) ispitanika; oni su popunjavali upitnik koji je sadržao devetnaest (19) pitanja, pored ostalih i ona koja smo ovde već naveli. S obzirom na to da je broj književnih

5 Takvi stavovi su, pored ostalog, u koliziji i sa činjenicom da su deca danas putem medija, interneta, video-igara neprestano izložena mnogobrojnim „reprezentacijama smrti”. V. Vukomanović Rastegorac, Crtani film i smrt: mogućnosti interpretacije filma „Sačekaj, molim te” Jelizavete Skvorcove, „Inovacije u nastavi” 2015, br. 4, s. 103.

${ }^{6}$ Istraživanje je obavljeno krajem aprila 2017. godine. Za kreiranje upitnika korišćena je aplikacija Gugl upitnik. Anketa je podeljena putem društvene mreže Fejsbuk, u grupi Profesori srpskog jezika <https://www.facebook.com/groups/151611781596379/>. Postavljena pitanja i dobijeni odgovori dostupni su za pregled na adresi $<$ https://drive.google.com/open?id=1Cqb_STn8G3nkrHCpK4tr5PGhQSfHArfp4bgD7uFeeBo. > Anketni upitnik priložen je na kraju ovog rada. 
tekstova u nastavnim programima za osnovnu i srednju školu u kojima je prisutan motiv smrti veliki, pažnju anketiranih nastavnika usmerili smo, primarno, ka onim delima u kojima je ovaj motiv centralni ili jedan od vodećih i odnosi se na smrt ljudskog bića, poput romana Anđele Naneti Moj deka je bio trešnja (1998), pripovedaka Bogojavljenska noć (1918) Svetozara Ćorovića, Kroz mećavu (1907) Petra Kočića, Povareta (1901) Sime Matavulja, Enciklopedija mrtvih (1983) Danila Kiša i drugih?.

Rezultati dobijeni anketiranjem u velikoj meri se podudaraju sa teorijskim uvidima o problematici dečijeg poimanja smrti koje nude psihološke i pedagoške studije, što nam omogućava formulisanje relativno jasnih stavova i postavljanje određenih teza koje mogu biti od koristi nastavnicima književnosti prilikom obrade ovakvih tekstova.

Dečije poimanje smrti je razvojnog karaktera, zavisi od uzrasta. Učenici osnovne i srednje škole (deca uzrasta od 12 godina i starija) o čijoj nastavi književnosti govorimo već imaju razvijenu sposobnost apstraktnog mišljenja, te su kognitivno sposobni da u velikoj meri usvojen koncept smrti - kao neminovne, univerzalne i ireverzibilne pojave (prema Spasić, 2014), i dalje razvijaju u pravcu potpuno zrelog shvatanja, u čemu im od velike pomoći mogu biti upravo razgovori na časovima književnosti ${ }^{8}$. Oni pokazuju svojevrsnu odbojnost prema temi (jer je neprijatna i zastrašujuća), ali istovremeno o njoj žele da govore kad god se za to ukaže prilika (jer imaju pregršt nedoumica a malo životnog iskustva). Nastavnici koje smo anketirali navode da srednjoškolci rado učestvuju u razgovorima o smrti i da ih ta tema izuzetno zanima (za razliku od učenika osnovne škole) ${ }^{9}$. Ovo je sasvim u skladu sa nekim istraživanjima čitalačkih interesovanja učenika, prema kojima starije tinejdžere i adolescente (starosti 15-20 godina) u književnosti najviše interesuju upravo velike, večite teme ljudske egzistencije (ljubav, život, bolest, snovi, smrt); to je životni period intenzivnih introspekcija, potrebe da istraže i spoznaju svoj unutrašnji svet u dodiru sa svetom koji ih okružuje, da izgrade stavove o važnim životnim pitanjima i uz pomoć književnih dela koja čitaju (najradije liriku i romane) kompenzuju manjak životnog iskustva ${ }^{10}$.

${ }^{7}$ Pogledati pitanje broj $6 \mathrm{u}$ anketnom upitniku i dobijene odgovore.

${ }^{8}$ Grafički predstavljeni rezultati odgovora na pitanje 18 pokazuju da najteže pojmljivom kategorijom za učenike nastavnici smatraju neminovnost smrti (označilo je 46,8\% anketiranih nastavnika), dok je racionalno prihvatljivija činjenica da smrt označava prestanak funkcionisanja bioloških procesa (manje od 13\% ispitanika označilo je ovu među ponuđenim opcijama odgovora).

${ }^{9}$ Nastavnik u anketi navodi primer komentara učenika sedmog razreda osnovne škole nakon čitanja Dnevnika Ane Frank: ,„Kad ćemo raditi nekog ko je živ i da je veseo?’ Tako na njih deluju književna dela u školi, vole, učestvuju, ali su im teška i tužna".

${ }^{10}$ Videti npr. klasifikaciju čitalačkih interesovanja prema uzrastu koje daju Sharlotte Buhler i Susanne Engelmann. One govore o tri razdoblja - tzv. Robinzonovom (9-11/12 godine), herojskom (12-15) i razdoblju lirike i romana (15-20 godine) (prema Kuvač -Levačić K., Razvoj i vrste čitanja, tipologija čitatelja s obzirom na čitanje «neknjiževnih» tekstova, [u:] Čitanje za školu $i$ život, IV Sipmozij učitelja i nastavnika hrvatskog jezika, zbornik radova, prir. M. Mićanović, 
S druge strane, proživljeno iskustvo učenika (starijih od sedam godina) sa smrću uglavnom doprinosi njenom zrelijem shvatanju, ali i tada to poimanje zavisi od uzrasta, senzibiliteta, okruženja i konkretnih okolnosti koje su do tog iskustva dovele ${ }^{11}$. Vrlo često takvo iskustvo intenzivira potrebu da se o njemu govori, kako bi se omogućilo prevladavanje određenog stanja (žalosti, uznemirenosti, anksioznosti i sl.) izazvanog gubitkom voljene/značajne osobe iz sopstvenog okruženja $^{12}$. Za učenike u takvoj situaciji razgovori o smrti u književnom delu mogu imati veliku ličnu vrednost, ali ne treba insistirati na tome da oni u njima učestvuju ukoliko za to nisu spremni ${ }^{13}$. Gledano iz ugla nastavnika, ohrabrujuće deluju i iskustva iz nastavne prakse koja svedoče o tome da razgovor o ličnom gubitku podstaknut nekim književnim tekstom, obavljen u učionici, na času, doprinosi međusobnom zbližavanju učenika i jačanju odeljenskog kolektiva. Dakle, od suštinske važnosti je usavršavanje veštine komunikacije i jačanje sposobnosti empatije sa osobama koje pate (koje su u žalosti zbog velikog gubitka, ili životno ugrožene zbog teške bolesti npr.), a nastava književnosti može u tim veštinama $i$ te kako osnaživati učenike ${ }^{14}$.

Zagreb 2013, s. 17-18). Ovo poslednje povezano je sa refleksijama o unutrašnjem životu, razmišljanjima o svetu i smislu života.

${ }^{11}$ M. Spasić, Strah od smrti kod dece (master rad, mentor prof. dr S. Vidanović), Departman za psihologiju, Filozofski fakultet Univerziteta u Nišu, 2014, s. 52-53.

${ }^{12}$ Ukoliko je proživljeno iskustvo smrti, mladoj osobi često je potrebna pomoć i vođstvo odraslog kroz proces žaljenja i suočavanja sa tim iskustvom, neko da ga sluša i sa njim razgovara; ona može osećati krivicu, ljutnju, čak i odgovornost za smrt koja se desila u njenom okruženju i uglavnom ne zna kako da upravlja svojim emocijama (javno i privatno). O ovome videti članak J.W. Worden, Talking To Children About Death, Compiled from Keynote Addresses at 1991 ADEC Annual Meeting, The Outstretched Hand Foundation, Australia, 1991. <https://www.hospicenet. org/html/talking-pr.html> [pristupljeno: 12.09.2017].

${ }^{13}$ Navodimo neke od odgovora iz ankete (20. pitanje) koji mogu predstavljati ilustraciju ove tvrdnje:

„Mali Princ - rastanak na kraju i pitanje da li je Mali Princ umro ili otputovao i razgovor koji se nametnuo o duhovnim vezama koje ostaju, o vrednosti onoga što si doživeo i kada to prođe, neminovnosti rastanka, lepota i tuga. Razgovor se vodio u odeljenju u kojem je učenik koji je nedavno izgubio sestru. Mislim da su mu razmišljanja i zaključci pomogli, ali on sam nije učestvovao u tom delu razgovora, slušao je. Učenici su zrelo komentarisali i delo im se dopalo." [Istakla S. B.]

„Devojčica kojoj je nedavno poginuo otac analizira Enciklopediju mrtvih i počinje glasno da se pita gde ona može pronaći takvu enciklopediju i šta tamo o njenom ocu piše.”

„Predavala sam Kamijevog Stranca u odeljenju u kojem je jedan od učenika izgubio oca oko mesec dana pre toga. Strepela sam, razgovarala sa psihologom i sve do samog časa nisam odlučila do koje mere ću temu smrti roditelja, koja je za ovaj roman vrlo važna, redukovati u razgovoru. Nisam očekivala da je ovaj učenik, inače neredovni čitalac, pročitao roman, a naročito s obzirom na okolnosti. U tom odeljenju dijalog je vrlo živ, te je temu bilo teško izbeći, kako je savetovala psihološkinja. Učenik se, međutim, vrlo zainteresovao za razgovr. Nije mnogo govorio, ali je posvećeno slušao i bilo je jasno da sluša o nečemu za njega vrlo važnom." [Istakla S. B.]

${ }^{14} \mathrm{U}$ tom smislu, dobro je znati da upravo rani razgovori omogućavaju da deca/učenici budu pokrenuti u pravcu izgradnje sopstvenog koncepta smrti. Metodički gledano, važan je uvid psiho- 
Anketirani nastavnici učeničko iskustvo sa smrću vide kao važan metodičko-oblikotvorni faktor koji će bitno usmeravati tok njihovih razgovora o književnom delu na času, jer moraju voditi računa o tome kakve reakcije učenika mogu izazvati pojedina pitanja koja u vezi sa tekstom postavljaju ${ }^{15}$. „U čitateljevu književnom doživljaju, tj. tekstualnom svijetu, predodžbe koje proizilaze iz teksta tako su tijesno isprepletane s onima koje proizilaze iz njegova prethodna znanja $i$ iskustva, da ih nije moguće jednostavno razrganičiti" 16 .

Pošto strah od smrti spada u grupu razvojnih strahova, tj. onih koji se uče/ usvajaju na osnovu modela preuzetih od roditelja/staratelja, to, indirektno, znači da i figura nastavnika može imati važnu ulogu u odnosu koji dete/učenik razvija prema smrti. Ne treba zanemariti ni činjenicu da na metodičko oblikovanje analitičkih razgovora o smrti kao temi/motivu iz književnog dela u velikoj meri utiču i stavovi samog nastavnika, njegovo iskustvo i lični odnos prema smrti, njegova religijska ili naučna uverenja, senzibilitet, interesovanja i sl. To je „prtljag” koji on unosi u svoju interpretaciju teksta i metodičko vođenje učenika tokom nastavnog razgovora.

Anketa je pokazala da naši nastavnici upravo u nastavi književnosti prepoznaju dragocene mogućnosti za ostvarivanje niza vaspitnih, saznajnih i praktičnih ciljeva u vezi sa složenom problematikom smrti. Razgovore o smrti oni smatraju generalno poželjnim u nastavi i, pripremajući se za njih, postavljaju jasno definisane vaspitne i praktične ciljeve ${ }^{17}$. Primenjuju, takođe, različite postupke motivisanja učenika za čitanje i proučavanje književnih dela sa istaknutim

loga da „odnos prema smrti i umiranju moramo izgrađivati i da nikada nije dovoljno rano s time započeti, naravno primjereno djetetovu uzrastu i mogućnostima razumijevanja. Samo tako ćemo moći izgraditi drukčiji odnos prema smrti i umiranju i kod odraslih osoba" D. Hercigonja-Kocijan, Psihološki aspekti umiranja i smrti, „Crkva u svijetu” 1998, br. 1, s. 28.

15 Čak 63,5\% anketiranih nastavnika odgovorilo je da njihovo metodičko postupanje na času u velikoj meri zavisi od uvida koji imaju u iskustvo učenika sa smrću i poznavanja činjenica o ne/ potpunosti porodica iz kojih dolaze. Na datom linku videti odgovore nastavnika na 12. pitanje u anketi.

${ }^{16}$ M. Grosman, U obranu čitanja: čitatelj i književnost u 21. stoljeću, prijev. A. Peti-Stantić, Zagreb 2010, s. 28-29.

${ }^{17}$ Prema navodima iz ankete, ciljevi se odnose na: podsticanje empatije i dubljeg razumevanja života i ljudskih postupaka, čovekoljublja; osposobljavanje učenika za razgovor o negativnim emocijama, bez obzira na neprijatnost koju takvi razgovori izazivaju; vaspitavanje učenika da ispoljavaju plemenita osećanja prema bližnjima, da se u teškim situacijama ne predaju, da pomažu jedni drugima i pronađu načina da govore o svemu što gubitak može da izazove; poimanje knjizevnosti kao slike života koji živimo, prihvatanje smrti kao nečeg prirodnog i neminovnog; formiranje realnog, ali optimističnog pogleda na ljudsku prolaznost i smrtnost, ukazivanje na trajnost, dugovekost ljudskog stvaralaštva i ljudskih dela: književna dela sa motivom smrti najbolji su primer takvog stanja stvari; uočavanje kako se motiv smrti u književnosti obrađuje na različite načine u zavisnosti od različitih uslova - mesta, vremena, likova, čak i biografije pisca, uz ukazivanje na svevremenost motiva i opšti ljudski udes kome se gotovo redovno suprotstavljaju motivi neprolaznosti umetnosti, ideala, ispunjenog života koji ublažava konačnost. Navedeni su samo neki od ciljeva, onako kako su ih u odgovorima definisali anketirani nastavnici (videti odgovore na 17. pitanje u anketnom upitniku). 
motivom smrti, na primer: uvodne razgovore koji podrazumevaju povezivanje teme sa prethodnim čitalačkim i, obazrivo, životnim iskustvom učenika, čitanje interesantnog odlomka, davanje istraživačkih zadataka; uspostavljanje veza sa znanjima koja učenici imaju iz drugih nauka/školskih predmeta (npr. istorija ili biologija), ukazivanje na veze sa filmom i gledanim pozorišnim predstavama, prezentovanje inserata iz različitih emisija i sl. ${ }^{18}$

$\mathrm{U}$ toku analitičkih razgovora o književnom tekstu u operativnom delu časa, sam pojam smrti nastavnik sa učenicima može tumačiti i obrazlagati, samo pominjati (u sklopu analize postupaka ili osećanja likova), a ima i nastavnika koji se trude da izbegnu produbljenije razgovore o ovoj temi ${ }^{19}$. Podaci dobijeni u anketi potvrđuju gledišta o postojanju izvesne nelagodnosti koju nastavnici osećaju kada na času treba da se bave temom smrti ${ }^{20}$.

Ukazujući na književna dela iz nastavnog programa koja smatraju neprimerenim uzrastu na kome su predviđena za obradu, nastavnici su navodili: odlomak iz Šekspirove drame Romeo i Julija (1597) u osmom razredu osnovne škole (navedeno više od dvadeset puta), epske pesme Smrt Majke Jugovića i Zidanje Skadra (sine anno), pripovetke Petra Kočića Kroz mećavu (1910) i Svetozara Ćorovića Bogojavljenska noć (1918), a u srednjoj školi Ep o Gilgamešu (2700. p.n.e.), Sofoklova Antigona (442. p.n.e.), Rekvijem (1952) Miodraga Pavlovića i dr. S druge strane, ima književnih tekstova koji se ne nalaze u programima iz književnosti, a trebalo bi; to su, prema mišljenju anketiranih nastavnika, dela: Čarobni breg (1924) Tomasa Mana (više navođenja), Lovac u žitu (1951) Dž. D. Selindžera, Moj život (1965) Ivana Cankara, Usta puna zemlje (1974) Branimira Šćepanovića, ali i Top je bio vreo (2008) Vladimira Kecmanovića i Islednik (2015) Dragana Velikića. Ovim predlozima nastavnika ${ }^{21}$ dodali bismo roman Knjige koje su progutale moga oca (2010) Alfonsa Kruza, Kuća hiljadu maski (2011) Igora Kolarova ili pak poemu Bajka o smrti (2016) Vladimira Vukomanovića, čime se, naravno, spisak mogućnosti ne iscrpljuje. Ove književne tekstove odlikuje osoben pristup temi smrti, neobičnost zapleta, likova ili forme. To su moderna, senzibilitetu savremenog mladog čitaoca bliska dela, koja bi se u nastavu književnosti mogla uključivati kao izborna lektira, ili makar u vidu preporuke učenicima za čitanje u slobodno vreme ${ }^{22}$.

${ }^{18} \mathrm{Na}$ datom linku videti odgovore na 8. pitanje.

${ }^{19}$ Pojam smrti u razgovoru sa učenicima tumači i obrazlaže 62,5\% ispitanika. Procenat onih koji pojam samo pominju je iznad očekivanog i iznosi $30,2 \%$, dok je procenat onih koji izbegavaju produbljeniji razgovor o temi $10,4 \%$.

${ }^{20}$ V. Vukomanović Rastegorac, Tumačenje poezije za decu kao mogućnost obrazovanja o smrti: zašto i kako, izlaganje na međunarodnom naučnom skupu Problemi i dileme savremene nastave u teoriji i praksi, Aranđelovac (Srbija), 26. i 27. 5. 2017 (rad u štampi).

${ }^{21} \mathrm{Na}$ podeljenom linku pogledati pitanje 7, b) i odgovore na njega.

22 Navodimo potpune reference: I. Kolarov, Kuća hiljadu maski, Beograd 2006; A. Kruz, Knjige koje su progutale moga oca, Beograd 2011; V. Vukomanović Rastegorac, Bajka o Smrti, Beograd 2016. 
Ako uzmemo u obzir književne tekstove koji se nalaze u programu obavezne školske lektire, odlomak iz pripovetke Bogojavljenska noć Svetozara Ćorovića ${ }^{23}$ čini se višestruko paradigmatičnim i pogodnim da na njemu ilustrujemo neke od aspekata teme koju ovim radom želimo da osvetlimo. Predstavićemo, ukratko, dve varijante metodičkog pristupa obradi ovog odlomka, koji bi se, u oba slučaja, mogao odrediti kao empatijsko-etički ${ }^{24}$.

Ćorovićevu ${ }^{25}$ priču o dečaku koji kraj samrtničke postelje svoje majke na Bogojavljensku noć ima samo jednu želju - da majka ozdravi, učenici šestog razreda osnovne škole doživljavaju vrlo snažno: oni se lako identifikuju sa glavnim junakom - dečakom približno njihovog uzrasta, a primenjeni umetnički postupci omogućavaju različite pristupe u njegovoj interpretaciji, počev od naslovom po-

${ }^{23}$ Tekst odlomka Bogojavljenska noć, [u:] S. Ćorović, Izabrane stranice. Srpska književnost u sto knjiga, prir. Ž. Milisavac, Knjiga 45, Novi Sad 1970, s. 27-31, <http://oso.rs/materijali/pdf/ Srpski6/03SNOHVATICE/17Bogojavljenska_noc.pdf $>$ [pristupljeno: 14.03.2017].

${ }^{24}$ Empatijsko-etički model teorijski je zasnovan na radovima o narativnoj empatiji Suzane Kin (Suzanne Keen), narativnoj etici Vejna Buta (Wayne Booth) i Marte Nusbaum (Martha Nussbaum); na istraživanju Martina Hofmana (Martin L. Hoffman) o odnosu empatije i moralnog razvoja ličnosti, zatim na studijama Patrika Kolm Hogana (Patrick Colm Hogan), Kita Outlija (Keith Oatley), Dejvida Mijala (David Miall), Noela Kerola (Noel Carroll) i drugih autora u oblasti afektivne naratologije i afektivne i kognitivne psihologije. Teoriju narativne empatije Suzan Kin (Suzanne Keen) postavlja u delu Emphaty and Novel, Oxford 2007, baveći se, primarno, narativnim tehnikama koje podstiču i pozitivno deluju na uspostavljanje empatijskog čitalačkog iskustva. Studija Martina L. Hofmana Empatija i moralni razvoj, prev. T. Šešum, Beograd 2003. predstavlja osnovu za svako ozbiljnije promišljanje fenomena empatije, nezavisno od konteksta. Etičkim aspektima književnih uticaja na razvoj ličnosti (čitaoca) Marta Nusbaum bavila se posebno u studiji Pjesnička pravda: književna imaginacija i javni život, Zagreb 2005 u kojoj je težište na isticanju potencijala književnosti u doprinosu ukidanju različitih stereotipa (rasnih, nacionalističkih, rodnih, verskih, klasnih...), što se postiže upravo zahvaljujući književnoj imaginaciji koja obezbeđuje snažan čitalački doživljaj i putem narativne empatije može da obezbedi pozitivno prosocijalno mišljenje i delovanje. Na našim prostorima empatijsko-etički model čitanja najpre je postuliran u radovima pojedinih hrvatskih autora i primenjen $u$ analizi književnih dela $u$ kojima je prepoznat potencijal za doprinos ukidanju nacionalističkih stereotipa izrazito prisutnih na području ratnih zbivanja na prostoru zapadnog Balkana devedesetih godina 20. veka (videti posebno: B. Vojnović, Empatija u književnosti: uloga lika u sabotaži nacionalističkih stereotipa i generalizacija, „Filološke studije” 2, 2012, br. 10, <https:// hrcak.srce.hr/138371> [pristupljeno: 17.03.2017]). Naš cilj je da ukažemo na metodičke potencijale empatijsko-etičkog modela čitanja, što je bila tema našeg izlaganja na naučnom skupu Književnost za decu u nauci i nastavi održanom 21. aprila 2017. godine u Jagodini (Srbija).

${ }^{25}$ Svetozar Ćorović (1875-1919) je srpski (hercegovački) pripovedač, romanopisac i dramski pisac. Starije istorije književnosti (J. Skerlić J., Istorija nove srpske književnosti, Beograd 2006; J. Deretić, Istorija srpske književnosti, Beograd 1996.) svrstavaju ga u grupu lirskih realista (Ćipiko, Kočić, Stanković), što danas predstavlja jasnu markaciju pripadnosti epohi moderne. Najpoznatija ostvarenja ovog stvaralački vrlo produktivnog pisca su zbirke pripovedaka $U$ časovima odmora (1903), Moji poznanici (1909), Komšije (1912); romani Ženidba Pere Karantana (1905), Majčina sultanija (1906), Stojan Mutikaša (1907), Jarani (1911), Među svojima (1921); drame Poremećen plan (1899), Zulumćar (1911), On (1913), Povratak (1913) i dr. 
stavljenog religijskog okvira ${ }^{26}$, preko motivske analize i uočavanja kontrastiranja motiva svetlosti i tame, siromaštva i bogatstva, bolesti i zdravlja, sna i jave, materijalnog i duhovnog - koji se u različitim vidovima u tekstu smenjuju, nudeći u, konačnom ishodu, otvoren kraj, kako bi ga učenici, shodno svojim shvatanjima i željama, ,popunili”. Činjenica da se u čitankama ne nalazi deo izvornog teksta u kome je sudbina majke razrešena (ona umire) predstavlja u metodičkom smislu dobro rešenje. Snažno doživljena i razgovorom produbljena priča pokreće kod učenika radoznalost i, otud, želju da pročitaju pripovetku u celini i saznaju njen kraj. Učenici su se, a da toga nisu ni svesni, našli na putu spoznaje da „fikcija deluje primarno preko emocija. Kada se emocija pojavi, to doživljavamo kao udar"27. Takvi doživljaji doprinose uticaju književnosti (pripovetke, romana, drame) „,na ceo identitet neke osobe”, spontano snažeći dugoročnu motivaciju za čitanje, odnosno potrebu (učenika) za knjigom ${ }^{28}$.

Pored toga, odlomak iz pripovetke Bogojavljenska noć podstiče i niz zanimljivih ideja za motivisanje učenika u uvodnom delu časa, koje bi bile u potpunosti u skladu sa načinom za koji su anketirani nastavnici većinski opredelili - da je polazište nastavnih razgovora o tzv. ,teškim” temama (poput teme smrti) optimistična, pozitivna emocija i razmišljanje $(76 \%)^{29}$. Čas tako može početi razgovorom o zvezdama padalicama i ličnim željama učenika; o razlozima zbog kojih nešto želimo; slušanjem duhovne muzike i podsećanjem na verovanja i običaje na Bogojavljenje; posmatranjem umetničkih slika sa motivima bliskim onima koji se javljaju u pripoveci ${ }^{30}$ - npr. Van Gog Noćno nebo (1889), Gustav Klimt Majka i dete (1905), Gotfrid Šalken Dama sa svećom (druga polovina XVII veka) i dr.

26 Jedan od mogućih pristupa ovoj pripoveci, njeno čitanje iz religijske vizure, otkriva se u zanimljivom komentaru nastavnika u odgovoru na anketno pitanje o upečatljivoj situaciji sa časa na kome je obrađivano delo sa motivom smrti. Odgovor navodimo u celini:,,Ove godine sam radila, kao saradnički, čas sa veroučiteljicom, sa temom Bogojavljenje - Bogojavljenska noć. Ona je sa pozicije veroučitelja i prema tome kako pravoslavni običaji i vera gledaju na smrt, objasnila deci zašto Bog nije uslišio dečakovu želju da majka ozdravi. Meni, kao nastavniku srpkog jezika, može biti zamereno ako bih na taj način protumačila događaj. U Čitanci je samo odlomak, ne daje se kraj, ali decu uvek interesuje da li je majka ozdravila, te je nemoguće ne odgovoriti deci i ispričati ili im ukazati da pročitaju kraj pripovetke.” (Videti odgovore na 20. anketno pitanje.)

${ }^{27}$ K. Oatley, Emotions and the story worlds of fiction, [u:] Narrative impact: Social and cognitive foundations, prir. M.C. Green, J. J. Strange, \& T. C. Brock, Mahwah-New Jersey 2002, s. 39-69. $<$ https://sites.google.com/site/keithoatleyhomepage/Home/articles> [pristupljeno: 19.04.2017].

28 Ovde ćemo se setiti Lava Vigotskog i njegove kulturno-istorijske teorije razvoja čoveka; umetnost je, prema Vigotskom, ,socijalna tehnika emocija, socijalno oruđe pomoću koga se u život socijalne grupe uključuju najintimnije i najličnije strane ljudskog bića. Čak bi bilo ispravnije da se kaže da emocije ne postaju socijalne, nego, naprotiv, lične, jer kada svako od nas doživljava proizvode umetnosti, te emocije postaju lične, a da pritom ne prestaju da budu socijalne." Zahvaljujući umetnosti „podržava se, kultiviše i oplemenjuje emocionalni razvoj pojedinca”. L. Vigotski, Dečja mašta i stvaralaštvo, prev. Lj. Milinčić, Beograd 2005, s. 90.

${ }^{29}$ Videti odgovore na 9. pitanje.

30 Ovaj vid motivisanja učenika - posmatranjem umetničkih motivski bliskih slika poznatih slikara primenile su nastavnice Vesna Čuković, Olivera Krstonosić i Valentina Rutović, OŠ Vuk 
U skladu sa izabranim metodičkim modelom, analitički razgovor o pripoveci vodiće otkrivanju ključnih elemenata teksta koji izazivaju narativnu empatiju; istraživanje načina na koji se postiže identifikacija čitaoca (učenika) s likom dečaka podrazumeva sagledavanje aspekata karakterizacije lika - opisa njegovog izgleda, postupaka, ambijenta u kome se nalazi, kao i pripovedne situacije. Iako se smatra da je pozicija homodijegetičkog naratora (pripovedanje u prvom licu, ja-forma) privilegovana tehnika za podsticanje narativne empatije, odnosno intenzifikator je identifikacije čitaoca sa likom, primetićemo da njeno odsustvo u ovoj priči ne umanjuje nivo uživljavanja i saosećanja čitaoca sa likom dečaka, što je postignuto upravo zahvaljujući primenjenim tipovima fokalizacije. U datom odlomku dominantna je pozicija sveznajućeg pripovedača (nulta fokalizacija) sa čestim spuštanjem na nivo unutrašnje fokalizacije. Primenjena tehnika učestalog smenjivanja gledišta pripovedača i perspektive lika (heterodijegetički narator i dečak kao fokalizator) pojačava empatiju čitaoca, dok je na planu unutrašnje kompozicije kompatibilna pomenutoj motivskoj dihotomiji. S pozicije sveznajućeg pripovedača dati su simbolički potentni opisi eksterijera i enterijera (kasabe obavijene gustim mrakom, sirotinjske sobe $\mathrm{u}$ kojoj treperi skoro potpuno dogorela sveća, bolesničke postelje u kojoj se gasi život majke), dok unutrašnju fokalizaciju dečaka obeležava poseban tip psihonaracije - pripovedana percepcija ${ }^{31}$. Ovde se naročito pažljivo treba pozabaviti dečakovom bogojavljenskom vizijom majke (,[...] kako se diže sa dušeka i ide njemu da ga zagrli. Ona bijaše sada tako lijepa, krepka, zdrava, kakvu je poznavao dok je bio vrlo mali [...]") ${ }^{32}$, zapravo ispitati funkciju njegovog sna u strukturi priče/odlomka, ali i na simboličkom planu. Značajno je, takođe, zapaziti kratke dijaloge koje dečak vodi s majkom (uz gest koji svedoči o nežnosti, velikoj ljubavi i brizi „A on je tiho pogladi po obrazu”) ${ }^{33}$ i njegovu molbu upućenu Bogu, koja se, refrenski, javlja na nekoliko mesta u tekstu (,Bože, da mi ozdravi majka!”) ${ }^{34}$.

Nakon analitičko-sintetičkog razgovora o tekstu, u završnom delu časa učenici dobijaju zadatak da osmisle način na koji bi svom prijatelju/prijateljici preporučili da pročita ovu pripovetku (u vidu kraćeg teksta, ilustracije, kreiranjem

Karadžić, Crvenka (Srbija); metodička priprema preuzeta je iz Baze znanja (2012/2013) Kreativne škole, sajta koji se svojevremeno nalazio na adresi www.kreativnaskola.rs.

31 Pripovedana percepcija - način na koji lik sagledava spoljašnje ili unutrašnje impulse. „Senzacije (informacije koje primamo čulima, samo elementi od kojih se sastoji percepcija) jesu sve vrste vizuelnih, auditivnih, olfaktivnih, taktilnih, gustativnih osećaja koji mogu biti doživljaji inicirani ,realnim' spoljašnjim okolnostima, ali i duboko unutrašnja stanja koja nemaju čvrste oslonce u ,realnom' okruženju, te tako mogu biti ili samo refleksija realnog okruženja, ili čisto unutrašnji osećaji aktivirani halucinacijama, snovima, somnabulnim stanjima.” O pripovedanoj percepciji pogledati rad: J. Vulović, Opis kao pripovedana percepcija u romanu ,Za kruhom ” Iva Ćipika, „Književna istorija" 2015, br. 47, s. 9-32.

32 Tekst odlomka S. Ćorović, Bogojavljenska noć, [u:] Izabrane stranice. Srpska književnost u sto knjiga, prir. Ž. Milisavac, Knjiga 45, Novi Sad 1970, s. 30, <http://oso.rs/materijali/pdf/Srpski6/03SNOHVATICE/17Bogojavljenska_noc.pdf> [pristupljeno: 14.03.2017].

33 Ibidem, s. 27.

${ }^{34}$ Ibidem, s. 29, 30. 
reklame - PPT prezentacije, trejlera, elektronskog postera ili stripa). Važno je da učenici iskažu sadržinu te preporuke. Alternativni zadatak mogao bi da bude da u formi kraće anotacije navedu razloge zbog kojih pripovetku ne bi preporučili, ili da dovrše priču na svoj način.

Drugi primer obrade odlomka predstavlja metodički koncept koji se od prikazanog standardnog (sa izraženijim fokusom na doživljajnoj komponeti) razlikuje po tome što u samo metodičko vođenje učenika uključuje postupak simulacije: naime, analitički razgovor zamišljen je tako da učenicima pitanja ,postavlja” dečak iz priče (nastavnik ili učenik u ulozi dečaka / ilustracija dečaka uz koju se na slajdovima pripremljene prezentacije emituju pitanja za učenike ${ }^{35}$ ili pak pitanja odštampana na nastavnom listu koja su formulisana tako da izgleda kao da ih postavlja glavni junak odlomka). Ovakav metodički pristup mogli bismo smatrati reprezentativnim primerom empatijsko-etičkog čitanja u nastavi, jer dobro ilustruje koncepte uosećanja (uživljavanja u lik koji pati) i saosećanja (koje podstiče empatiju prema osobi koja pati), o kojima govori Suzan Kin. Saosećanje se može podsticati i razvijati i pitanjima tipa: Zamisli da si ti najbolji drug/drugarica dečaka iz priče. Kako bi se ponašao prema prijatelju? Razmisli kojim rečima ili postupcima bi ga utešio i sl. Podjednako funkcionalna, mada udaljenija od teksta mogu biti pitanja i nalozi koji predstavljaju njegovu aktuelizaciju, povezivanje sa realnim životnim iskustvom učenika, značajno zbog ostvarivanja vaspitnih i funkcionalnih ciljeva (Šta bi ti poželeo na Bogojavljenje? / Napiši šta radiš kada je neko u tvojoj kući bolestan. Koju molitvu izgovaraš? / Seti se drugova kojima bi tvoja pomoć bila dragocena. Kako bi im pomogao? /Šta si naučio iz ove priče? i dr. $)^{36}$.

Da zaključimo - argumenata koji idu u prilog stavu da tema smrti u nastavi književnosti ne bi trebalo da se izbegava ima dovoljno, toliko da, zapravo, potvrđuju suprotno - da je ona višestruko poželjna ${ }^{37}$. Značajno je da se nastavnici studiozno i znalački bave književnim delima o smrti, da horizonte potisnutog ili pokazanog interesovanja učenika o ovoj temi bogate upravo iskustvom čitanja o tome, snažnim doživljavanjem i razvijanjem njihove sposobnosti empatije sa osobama koje pate, jer se kao takvi izgrađuju u individue sa zrelim odnosom

35 Ovu ideju osmislila je i realizovala nastavnica Nataša Stojanović, OŠ Ivan Goran Kovačić, Niška Banja (Srbija); prezentacija jedostupna na $<$ https://www.slideshare.net/vresa/bogojavljenska-noc> [pristupljeno: 13.09.2017].

36 Pitanja u zagradi preuzeta su iz prezentacije Nataše Stojanović (vidi fusnotu 25).

${ }^{37}$ Pored Vukomanovićevog rada koji je ovde već citiran (vidi fusnotu 2), iscrpne, teorijski podrobno utemeljene odgovore na pitanja o prisustvu i načinu obrade književnih tekstova s dominantnim motivom smrti isti autor daje u studiji „Tumačenje poezije za decu kao mogućnost obrazovanja o smrti: zašto i kako" (2017, u štampi). Uvodeći u svoje razmatranje pojam obrazovanja o smrti (death education), Vukomanović ispituje mogućnost njegovog zasnivanja ili bar delimične implementacije unutar postojećih školskih predmeta. Zato je u drugom delu rada fokusiran na časove srpskog jezika i književnosti i moguće načine interpretacije poezije za decu u kojoj dominira motiv smrti. Videti: V. Vukomanović Rastegorac, Tumačenje poezije za decu kao mogućnost obrazovanja o smrti: zašto i kako, izlaganje na međunarodnom naučnom skupu Problemi i dileme savremene nastave u teoriji i praksi, Aranđelovac (Srbija), 26. i 27.05.2017 (rad u štampi). 
prema životnoupravljajućoj pojavi smrti; to će im omogućiti da budu/postanu korisni članovi užih (porodičnih) i širih društvenih zajednica kojima pripadaju, ali i sami svoj oslanac u životnim nedaćama koje predstavljaju neminovnost. Promišljanja i razgovore o književnim delima koja obrađuju problematiku smrti treba stalno pokretati i proširivati uključivanjem i novih umetnički vrednih tekstova (koji se ne nalaze u školskim programima), a koji, zajedno sa onim kanonskim, svedoče o neodvojivosti umetnosti/književnosti od života i neodvojivosti života od smrti; o lepoti, vrednosti i smislu - i umetnosti i života. Svaki nastavnički uspeh u ostvarivanju niza saznajnih, funkcionalnih i vaspitnih ciljeva pri obradi ovakvih književnih tekstova najbolji je dokaz neodrživosti određenja teme smrti kao tabu teme u učionici.

\section{Bibliografija}

Deretić J., Istorija srpske književnosti, Beograd 1996.

Grosman M., U obranu čitanja: čitatelj i književnost u 21. stoljeću, prijev. A. Peti-Stantić, Zagreb 2010.

Hercigonja-Kocijan D., Psihološki aspekti umiranja i smrti, „Crkva u svijetu” 1998, br. 1.

Hofman M. L., Empatija i moralni razvoj, prev. T. Šešum, Beograd 2003.

Keen S., Empathy and Novel, Oxford 2007.

Kuvač-Levačić K., Razvoj i vrste čitanja, tipologija čitatelja s obzirom na čitanje «neknjiževnih» tekstova, [u:] Čitanje za školu $i$ život, IV Sipmozij učitelja i nastavnika hrvatskog jezika, zbornik radova, prir. M. Mićanović, Zagreb 2013.

Mrkalj Z., Na časovima srpskog jezika i književnosti, Beograd 2011.

Nikolić M., Metodika nastave srpskog jezika i književnosti, Beograd 2006.

Nusbaum M., Pjesnička pravda, prijev. M. Miladinov, Zagreb 2005.

Nusbaum M., Negovanje čovečnosti: klasična odbrana reforme liberalnog obrazovanja, prev. S. Glišić, „Reč” 2012, br. 82/28.

Oatley K., Emotions and the story worlds of fiction, [u:] Narrative impact: Social and cognitive foundations, prir. M. C. Green, J. J. Strange, \& T. C. Brock, Mahwah-New Jersey 2002, s. 39-69, $<$ https://sites.google.com/site/keithoatleyhomepage/Home/articles> [pristupljeno: 19.04.2017].

Skerlić J., Istorija nove srpske književnosti, Beograd 2006.

Spasić M., Strah od smrti kod dece, (master rad, mentor prof. dr S. Vidanović), Departman za psihologiju, Filozofski fakultet Univerziteta u Nišu, 2014.

Vigotski L., Dečja mašta i stvaralaštvo, prev. Lj. Milinčić, Beograd 2005.

Vojnović B., Empatija u književnosti: uloga lika u sabotaži nacionalističkih stereotipa igeneralizacija, „Filološke studije” 2, 2012, br. 10, <https://hrcak.srce.hr/138371> [pristupljeno: 17.03.2017].

Vukomanović Rastegorac V., Crtani film i smrt: mogućnosti interpretacije filma Sačekaj, molim te Jelizavete Skvorcove, „Inovacije u nastavi” 2015, br. 4.

Vukomanović Rastegorac V., Tumačenje poezije za decu kao mogućnost obrazovanja o smrti: zašto $i$ kako, izlaganje na međunarodnom naučnom skupu Problemi $i$ dileme savremene nastave u teoriji i praksi, Aranđelovac (Srbija), 26. i 27.05.2017 (rad u štampi).

Vulović J., Opis kao pripovedana percepcija u romanu „Za kruhom” Iva Ćipika, „Književna istorija" 2015, br. 156. 


\section{Prilog}

\section{Anketni upitnik ${ }^{38}$}

Poštovana koleginice, poštovani kolega,

Za potrebe manjeg istraživanja o načinima metodičke obrade motiva smrti u nastavi književnosti, molimo Vas da odgovorite na postavljena pitanja. Vaše iskustvo u praksi dragoceni je izvor metodičko-teorijskih zaključaka.

Rezultati ankete biće upotrebljeni isključivo u naučne svrhe. Unapred zahvaljujemo na utrošenom vremenu i strpljenju.

1. Pol: muški

ženski

2. Broj godina radnog staža koji imate u nastavi:
$1-5$
$5-15$
$15-25$
preko 25

3. Zaposleni ste $\mathrm{u}$ :

osnovnoj školi

srednjoj školi /gimanziji

4. Razredi kojima predajete u ovoj školskoj godini:

(osnovna škola) peti, šesti, sedmi, osmi

(srednja škola) prvi, drugi, treći, četvrti

5. Književni tekstovi u kojima je istaknut motiv smrti ljudskog bića zahtevaju osoben/pažljiviji metodički pristup i pripremu nastavnika:

- u velikoj meri

- ne naročito

- ne zahtevaju osoben pristup

6. Označite tekstove sa istaknutim motivom smrti čija nastavna obrada za Vas predstavlja veći metodički izazov u odnosu na uobičajena postupanja.

Osnovna škola: Anđela Naneti, Moj deka je bio trešnja; Danilo Kiš, Rani jadi; Svetozar Ćorović, Bogojavljenska noć;

Srednja škola/gimnazija: Sofokle, Antigona; Ep o Gilgamešu; Čehov, Tuga; Miodrag Pavlović, Rekvijem; Danilo Kiš, Enciklopedija mrtvih; Simo Matavulj, Povareta; Šekspir, Romeo i Julija; Isidora Sekulić, Kronika palanačkog groblja;

${ }^{38}$ Zbog ograničenog prostora, izgled upitnika modifikovan je izostavljanjem prostora za unošenje odgovora. Originalna verzija upitnika, kao i dobijeni odgovori dostupni su za pregled na adresi https://drive.google.com/open?id=1Cqb_STn8G3nkrHCpK4tr5PGhQSfHArfp4bgD7uF eeBo. 
7. Koje postupke motivisanja učenika primenjujete za čitanje i analizu književnih tekstova sa istaknutim motivom smrti? Opišite najefektnije.

8. Polazište nastavnog razgovora tada je obično:

a) pozitivna, optimistična emocija i razmišljanje

b) negativna, pesimistička emocija i razmišljanje

c)

9. Tekstove sa istaknutim motivom smrti emocionalnije doživljavaju:
a) devojčice
b) dečaci
c) nema razlike
d)

10. U toku analitičkog razgovora o tekstu, sam fenomen/pojava smrti se:

- samo pominje (u sklopu analize postupaka ili osećanja likova)

- objašnjava i obrazlaže (učenici se podstiču na razgovor o smrti)

- izbegava se produbljeniji razgovor o toj temi

11. U kojoj meri je Vaše metodičko postupanje uslovljeno uvidom koji imate u iskustvo Vaših učenika sa smrću i znanjem o ne/potpunosti porodica iz kojih dolaze?
a) u velikoj meri
b) neznatno
c) uopšte nije uslovljeno time

12. Vaše iskustvo pokazuje da učenici prema tekstovima sa istaknutim motivom smrti
a) pokazuju otpor i nemotivisanost za čitanje i analizu
b) pokazuju izrazito interesovanje za čitanje i analizu
c) pokazuju uobičajeni nivo interesovanja za čitanje i analizu

13. Prilikom nastavne obrade tekstova sa istaknutim motivom smrti više insistirate na
a) učeničkom doživljaju teksta i njegovoj verbalizaciji
b) analitičkosintetičkom sagledavanju umetničkih osobenosti teksta
c) podjednako na doživljaju i analizi
d) stvaralačkim aktivnostima učenika nakon obrade književnog teksta

14. Učenici koji imaju iskustvo smrti (gubitka) bliske osobe (ili kućnog ljubimca) pokazuju, prema Vašim uvidima:
a) zrelije razumevanje smrti
b) da iskustvo pozitivno utiče na njihovo razumevanje
c) da iskustvo negativno utiče na njihovo razumevanje
d) da ne postoji veza između iskustva i razumevanja samog fenomena smrti / književnog teksta sa motivom smrti
e)

15. U Vašim pripremama za obradu tekstova sa istaknutim motivom smrti naglašenija je
a) vaspitna funkcija analitičkih razgovora
b) saznajna funkcija analitičkih razgovora
c) 
16. Na koji način obradu tekstova sa istaknutim motivom smrti povezujete sa vaspitnim ciljevima nastave književnosti koju realizujete?

17. Označite supkomponente smrti koje učenici, prema Vašem mišljenju, najteže shvataju:
a) neminovnost
b) univerzalnost
c) ireverzibilnost
d) prestanak funkcionisanja bioloških procesa
e) uzročnost

18. Smatrate li razgovor o smrti (odnosno književne tekstove u kojima je motiv smrti vodeći) generalno poželjnim u nastavi književnosti? Obrazložite zbog čega.

19. Opišite kratko upečatljivu situaciju sa časa obrade teksta sa istaknutim motivom smrti koja je za Vas imala posebnu vrednost u profesionalnom (stručnom?) ili drugom smislu.

\section{The motif of death in teaching literature}

\section{Summary}

This paper includes a survey of the affective and cognitive limitations in the students' perception of the motif of death, particularly when it appears as the main theme in literary works analyzed in class. The author explores the frequency of such texts in the curriculum and provides specific psychological-pedagogical findings, which should be considered and applied. Furthermore, the paper contains certain methodological solutions applicable in some stages of interpretation that refer to the analysis of the motif of death. The solutions, on the one hand, take into consideration the values and the significance of the work itself, and on the other hand, the age of students and their individual characteristics (such as personality, sensibility, the experience of the death of their loved ones or its lack). The insights and suggestions are related to the results of an online questionnaire conducted among teachers of literature about their approach to the motif of death in teaching, which is presented in this paper.

Keywords: the motif of death, affection, empathy, the methodology of teaching literature

\section{Анализ мотива смерти на уроках литературы в школе}

\section{Резиме}

В статье рассматриваются аффективные и когнитивные ограничения в восприятии мотива смерти школьниками, особенно в том случае, когда этот мотив является одним из ведущих в литературном произведении, анализируемом на уроке литературы. Исследуется количество таких текстов в учебной программе, анализируются определенные психологопедагогические знания, которые надо учитывать в учебном процессе. Предлагаются 
методические рекомендации по интерпретации мотива смерти. С одной стороны, эти рекомендации учитывают ценность и значение самого литературного текста, а с другой возраст и другие индивидуальные характеристики учащихся (характер, чувствительность, опыт/отсутствие опыта). Выводы и предложения в статье сопоставляются с результатами проведенного среди преподавателей литературы онлайн-опроса, касающегося методики интерпретации мотива смерти на уроках литературы. В статье представлены результаты проведенного опроса.

Ключевые слова: мотив смерти, аффект, эмпатия, методика преподавания литературы 